\title{
PENERAPAN PENDEKATAN KONTEKSTUAL MENGGUNAKAN MEDIA GAMBAR UNTUK MENINGKATKAN KETERAMPILAN MENULIS DESKRIPSI PADA SISWA KELAS II SEKOLAH DASAR
}

\author{
Darmatul Asma Toja \\ SD Inpres Bhoanawa 2 Ende, NTT \\ Jln.Ikan Duyung, Kelurahan Rukun Lima, Ende, NTT \\ * Corresponding Author: darmatulasma@gmail.com
}

\begin{abstract}
Info Artikel Abstract
Sejarah Artikel: Diterima: 18/09/2020

Direvisi: 20/09/2020

Disetujui:30/09/2020

Keywords:

Animal Image media, Writing Skills

This research was conducted because it was found that there were problems in the Indonesian language subject for grade II students of Bhoanawa 2 Impres Elementary School which showed very low Indonesian learning outcomes. The formulations of the problems in this study are: 1) Does learning through a contextual approach by utilizing animal image media can improve writing writing skills ?; 2) Can a contextual approach using animal pictures media increase student activity? The data collection methods used were: observation, interview, test and documentation. The subjects in this study were all students in grade II of the Bhoanawa 2 Impres Elementary School, totaling 17 people. This type of research is Classroom Action Research. The results showed that the increase in writing skills in writing was $29 \%$, or only 5 out of 17 students who were able to write well, which could achieve a greater value of 67. The results of cycle I increased to $47.05 \%$ (less) because of 17 students 8 students who managed to get a score above the value of the Minimum Completeness Criteria, and in cycle II an increase of $88.23 \%$ (very good), of the 17 students sampled there were 5 students in the very good category and 10 students in the good category.
\end{abstract}

\begin{abstract}
Abstrak
Penelitian ini dilakukan karena ditemukan masalah pada mata pelajaran Bahasa Indonesia siswa kelas II Sekolah Dasar Impres Bhoanawa 2 yang menunjukkan hasil belajar bahasa indonesia yang sangat rendah. Rumusan masalah dalam penelitian ini adalah: 1) Apakah pembelajaran melalui pendekatan kontekstual dengan memanfaatkan media gambar binatang dapat meningkatkan keterampilan mendeskripsi secara tertulis?; 2) Apakah pendekatan kontekstual dengan memanfaatkan media gambar binatang dapat meningkatkan aktivitas siswa?. Metode pengumpulan data yang digunakan adalah: observasi, wawancara, test dan dokumentasi. Subyek dalam penelitian ini adalah semua siswa kelas II Sekolah Dasar Impres Bhoanawa 2 yang berjumlah 17 orang. Jenis penelitian ini adalah Penelitian Tindakan Kelas. Hasil penelitian menunjukan bahwa peningkatan keterampilan mendeskripsi secara tertulis sebesar 29\%, atau hanya 5 siswa dari 17 siswa yang mampu menulis dengan baik yakni dapat mencapai nilai lebiah besar 67. Hasil siklus I meningkat menjadi 47,05\% (kurang) karena dari 17 siswa 8 siswa yang berhasil memperoleh nilai di atas standar Kriteria Ketuntasan Minimum, dan pada siklus II mengalami peningkatan sebesar 88,23\% (sangat baik), dari 17 siswa yang dijadikan sampel ada 5 siswa dalam kategori sangat baik dan 10 siswa dalam kategori baik.
\end{abstract}

\footnotetext{
*Alamat korespondensi:

SD Inpres Bhoanawa 2 Ende, NTT

Jln.Ikan Duyung, Kelurahan Rukun Lima, Ende, NTT

E-mail : darmatulasma@gmail.com

(c) 2020 Program Studi PGSD Universitas Flores Email: primagistrauniflor@gmail.com
} 


\section{PENDAHULUAN}

Bahasa memiliki peran penting dalam perkembangan intelektual, sosial, dan emosional peserta didik dalam mempelajari semua bidang studi (Zamzani, 2014). Salah satu ketrampilan berbahasa yang penting adalah menulis. Keterampilan menulis sangat penting untuk dikuasai oleh siswa karena dengan menulis siswa dapat leluasa dalam mengekspresikan ide, pikiran, dan gagasannya kepada orang lain melalui tulisan (Nugraha, Zuleha \&Fuad, 2019). Kenyataannya banyak peneliti yang melaporkan bahwa mata pelajaran Bahasa Indonesia dianggap membosankan bahkan dianggap remeh oleh para siswa. Lakilaf \& Suarjana (2017) menyatakan bahwa salah satu aspek pembelajaran bahasa yang juga dianggap remeh oleh siswa adalah aspek menulis. Hal ini juga dialami peneliti sendiri. Siswa banyak yang acuh tak acuh dengan mata pelajaran ini sehingga banyak siswa yang mengalami kesulitan dalam menulis.

Pengalaman peneliti, banyak siswa yang kesulitan dalam menulis. Hal ini dapat diketahui ketika siswa diminta untuk menulis sebuah karangan sederhana, mendeskripsikan suatu benda ataupun ketika menulis puisi, mereka sering mengeluh dan terlihat bingung dengan apa yang ingin mereka tulis. Masalah yang terjadi pada siswa kelas II yang penulis alami adalah kurangnya pemahaman siswa terhadap cara mendeskripsikan suatu benda. Hal itu dapat diketahui dari rendahnya hasil tes pada mata pelajaran Bahasa Indonesia aspek menulis dengan tujuan pembelajaran mendeskripsikan binatang secara tertulis.

Berdasarkan permasalahan ini setelah melalui refleksi pembelajaran yang penulis lakukan maka perlu tindakan, yakni dengan mencari dan menggunakan suatu pendekatan atau model pembelajaran yang efektif, inovatif, dan berpotensi memperbaiki pembelajaran menulis, sehingga meningkatkan minat, motivasi, dan sikap siswa terhadap pembelajaran menulis yang berakibat pada meningkatnya prestasi belajar siswa. Untuk itulah guru (peneliti) merancang suatu bentuk pembelajaran yang aktif, kreatif, efektif, dan menyenangkan melalui pendekatan kontekstual dengan media gambar sebagai media alternatif untuk memperbaiki pembelajaran menulis.

Berdasarkan latar belakang yang telah diuraiakn di atas, maka penelitian ini akan berfokus pada hal-hal yang berkaitan dengan upaya mendayagunakan media gambar binatang sebagai sarana pembelajaran berbasis kontekstual sehingga dapat meningkatkan keterampilan siswa kelas II SDI Bhoanawa 2 Kecamatan Ende Selatan Kabupaten Ende dalam mendeskripsi secara tertulis.

\section{METODE PENELITIAN}

Penelitian ini menggunakan pendekatan kualitatif. Pendekatan ini berkenaan dengan perbaikan atau peningkatan hasil belajar pada suatu kelas. Berdasarkan metodologinya, penelitian ini merupakan jenis penelitian tindakan kelas (PTK), karena penelitian ini mencermati dan mengatasi masalah pembelajaran di kelas. Penelitian ini dilaksanakan di kelas II SDI Bhoanawa 2 Kecamatan Ende Selatan Kabupaten Ende pada Tahun 2019/2020 dengan 17 Siswa sebagai subyek penelitian. Dalam penelitian tindakan kelas ini peneliti berkolaborasi dengan teman sejawat untuk membantu terutama dalam proses pengumpulan data.

\section{HASIL DAN PEMBAHASAN}

\section{Hasil Penelitian}

Prosentase hasil kemampuan mandeskripsi secara tertulis pada prosentase hasil pembelajaran pada siklus I adalah sebesar $47,05 \%$ dan siklus II adalah sebesar 88,23\%. Hal ini berarti ada peningkatan hasil keterampilan mendeskripsi secara tertulis pada siklus II sebesar $41,18 \%$ yakni dari kategori kurang menjadi kategori sangat baik. Hal ini dapat di lihat pada penjelasaan tabel di bawah ini.

\section{a. Hasil Belajar Siswa Siklus 1}

Hasil kemampuan/keterampilan mendeskripsi secara tertulis tentang seekor binatang "Ayam" pada tindakan siklus I dapat dilihat pada Tabel 1 berikut:

Tabel 1.

Kemampuan/Keterampilan Mendeskripsi Secara Tertulis Siklus I 
Darmatul Asma Toja

Penerapan Pendekatan Kontekstual Menggunakan Media Gambar untuk Meningkatkan Keterampilan Menulis Deskripsi pada Siswa Kelas II SDI Bhoanawa

Prima Magistra: Jurnal Ilmiah Kependidikan Volume 1, Nomor 2, Oktober 2020, hal 199-204

\begin{tabular}{|c|c|c|c|c|c|}
\hline Kategori & Interval Nilai & Frek. & $\%$ & \multicolumn{2}{|c|}{ Keterangan } \\
\hline Sangat baik & $85-100$ & 1 & 6 & \multicolumn{2}{|c|}{ Prosentase } \\
\hline Baik & $70-84$ & 7 & 41 & \multirow{2}{*}{$\mathrm{P}=\frac{\mathrm{R}}{\mathrm{T}}$} & \multirow{2}{*}{ X $100 \%$} \\
\hline Sedang & $55-69$ & 7 & 41 & & \\
\hline Kurang & $40-54$ & 2 & 12 & \multirow{3}{*}{$\begin{aligned} P & =\frac{8}{17} \\
& =47,05 \%\end{aligned}$} & \multirow{3}{*}{ X $100 \%$} \\
\hline Sangat kurang & $0-39$ & 0 & 0 & & \\
\hline & & & & & \\
\hline Jumlah & & 17 & & Kurang & \\
\hline
\end{tabular}

Dari Tabel 1 di atas, hasil kemampuan atau keterampilan mendeskripsi secara tertulis dapat disimpulkan :

1) Secara prosentase keterampilan mendeskripsi secara tertulis siswa kelas II pada tindakan siklus I masih kurang yaitu $47,05 \%$

2) Dari 17 siswa yang meiliki keterampilan mendeskripsi secara tertulis dengan sangat baik ada 1 siswa (6\%), memiliki keterampilan baik ada 7 siswa $(41 \%)$, berketerampilan sedang ada 7 siswa (41\%), berketerampilan mendeskripsi secara tertulis kurang ada 2 siswa (12\%).
3) Secara umum hampir sebagian siswa belum terampil dalam mendeskripsi secara tertulis.

4) Hampir sebagian siswa belum terampil dalam menulis dengan menggunakan pemilihan kata yang tepat dan tulisan yang rapi.

\section{b. Hasil Belajar Siswa Siklus II}

Hasil belajar kemampuan/ keterampilan mendeskripsi secara tertulis pada tindakan siklus II dapat dilihat pada tabel berikut:

Tabel 2.

Kemampuan/Keterampilan Mendeskripsi Secara Tertulis Siklus II

\begin{tabular}{|l|c|c|c|c|}
\hline \multicolumn{1}{|c|}{ Kategori } & Interval Nilai & Frek. & $\%$ & Keterangan \\
\hline Sangat baik & $85-100$ & 5 & 29 & Prosentase \\
Baik & $70-84$ & 10 & 59 & $\mathrm{P}=\frac{\mathrm{R}}{\mathrm{T}} \mathrm{X} \mathrm{100 \%}$ \\
Sedang & $55-69$ & 2 & 12 & 0 \\
Kurang & $40-54$ & 0 & 0 & $\mathrm{P}=\frac{15}{17} \mathrm{X} \mathrm{100 \%}$ \\
Sangat kurang & $0-39$ & 0 & $08,23 \%$ \\
& & & & $=88$, \\
\hline Jumlah & & 17 & 100 & Sangat Baik \\
\hline
\end{tabular}

Dari daftar tabel hasil kemampuan atau keterampilan mendeskripsi secara tertulis dapat disimpulkan:

1) Secara prosentase keterampilan mendeskripsi secara tertulis siswa kelas II pada tindakan siklus II mengalami peningkatan yaitu 88,23 $\%$.

2) Dari 17 siswa yang memiliki keterampilan mendeskripsi secara tertulis dengan sangat baik ada 5 siswa (29\%), memiliki keterampilan baik ada 10 siswa (59\%), berketerampilan sedang ada 2 siswa $(12 \%)$.

3) Secara umum hampir semua siswa sudah terampil dalam mendeskripsi secara tertulis. 
4) Hampir semua siswa terampil dalam menulis dengan menggunakan pilihan kata yang tepat dan tulisan yang rapi.

Melalui pembelajaran kontekstual dengan mendayagunakan puzzle (potongan gambar) binatang dapat meningkatkan keterampilan siswa dalam mendeskripsi secara tertulis, semangat siswa, daya imajinasi siswa dan partisipasi aktif siswa dalam kelompok dan antar siswa di dalam proses pembelajaran.

\section{Pembahasan}

Hasil studi pendahuluan dalam penelitian tindakan ini dari 17 jumlah siswa kelas II tahun pelajaran 2019/2020 SDI Bhoanawa 2 Kecamatan Ende Selatan kabupaten Ende yang mampu mendeskripsi secara tertulis dengan baik dan memperoleh nilai di atas 67 (nilai KKM menulis) ada 5 siswa atau hanya $29 \%$. Dari hasil prosentase yang sangat kurng inilah maka diadakan atau ditindaklanjuti dengan usaha-usaha perbaikan pembelajaran yaitu dengan melaksanakan tindakan atau siklus I, melalui pembelajaran kontekstual dengan mendayagunakan gambar binatang sebagai media utama dalam pelaksanaan siklus.

Dari hasil pelaksanaan pembelajaran pada Siklus I secara prosentase kemampuan/keterampilan mendeskripsi secara tertulis terjadi peningkatan yang cukup signifikan yakni sebesar $18,05 \%$, atau tepatnya sebelum dilaksanakan tindakan prosentase yang dicapai sebesar 29\% meningkat menjadi 47,05\% setelah dilaksanakan siklus I.

Berdasarkan hasil observasi dan analisis, meskipun Siklus I ini terjadi peningkatan hasil keterampilan mendeskripsi secara tertulis namun masih dalam kategori kurang.Hal ini dapat dilihat karena dari sebagian besar siswa masih belum bisa menulis dengan baik, karena pilihan kata yang digunakan belum tepat.Selain itu tulisan yang disajikan juga belum terlihat rapi dan cenderung acak-acakan sehingga sukar dibaca. Adapun cara mengatasi masalah ini, guru menggunakan pembelajaran kontekstual dengan mendayagunakan media gambar binatang dalam hal ini ayam sebagai alternatif pembelajaran. Gambar ayam dipilih sebagai media karena binatang tersebut sudah dikenal baik oleh siswa sehingga tidak terlalu sulit bagi siswa untuk mendeskripsikannya.

Tindakan II atau siklus II lebih berhasil dibanding dengan tindakan/siklus I dengan hasil prosentase $88,23 \%$ dalam kategori sangat baik, sedangkan hasil prosentase tindakan I adalah $47,05 \%$. Hal ini berarti ada peningkatan hasil sebesar $41,18 \%$. Peningkatan hasil pada siklus II ini disebabkan karena guru lebih kreatif dan imajinatif yakni dengan menggunakan puzzle (potongan gambar). Dampak ataupun hasil dari penggunaan media tersebut sangat positif, sebab siswa jadi tertarik dan responsif serta gembira dalam belajar. Dengan perasaan yang senang maka bukan tidak mungkin jika hasil pembelajaran pun akan meningkat karena dengan rasa senang maka siswa akan lebih mudah berpikir dan menuliskan apa yang dipikirkannya sesuai dengan gambar yang telah tersusun dengan baik.

Selain dengan media pembelajaran yang lebih variatif, dengan metode kelompok belajar juga memudahkan siswa untuk mendeskripsi dengan baik. Hal itu karena dengan berkelompok, siswa lebih mudah untuk bertukar pikiran dan menambah pengetahuan tentang objek yang akan dideskripsikan, sehingga siswa dapat menulis dengan baik. Dengan kelompok belajar dapat meningkatkan sikap bersahabat dan kepedulian siswa terhadap teman-temannya.

Dengan demikian penelitian tindakan kelas dengan mengambil mata pelajaran Bahasa Indonesia pada pembelajaran mendeskripsi secara tertulis melalui penerapan pembelajaran kontekstual dengan memanfaatkan gambar binatang sebagai media utama dalam pembelajaran berhasil sesuai dengan harapan yaitu dapat meningkatkan prestasi belajar siswa khususnya meningkatkan keterampilan mendeskripsi secara tertulis pada siswa kelas II Semester II SDI Bhoanawa 2 Kecamatan Ende Selatan Kabupaten Ende.

\section{SIMPULAN DAN SARAN}

Berdasarkan hasil penelitian tentang penerapan pembelajaran kontekstual untuk meningkatkan keterampilan mendeskripsi secara tertulis pada siswa kelas II Semester II 
SDI Bhoanawa 2 Kabupaten Ende dapat disimpulkan sebagai berikut:

1. Kegiatan pembelajaran mendeskripsikan secara tertulis pada siswa kelas II SD dilaksanakan berdasarkan aspek-aspek kemampuan/keterampilan yang harus dimiliki oleh siswa sesuai indikatorindikator berikut:

a). Siswa dapat mendeskripsi secara tertulis dengan pilihan kata yang tepat.

b). Siswa dapat menyajikan tulisan dengan bentuk tulisan yang rapi.

c). Siswa dapat mendeskripsi binatang dalam bentuk kalimat tebak-tebakan.

2. Proses pelaksanaan pembelajaran mendeskripsi secara tertulis melalui penerapan pembelajaran kontekstual dengan memanfaatkan media gambar binatang dapat meningkatkan keterampilan mendeskripsi secara tertulis siswa kelas II Semester II SDI Bhoanawa 2 Kabupaten Ende. Peningkatan keterampilan mendeskripsi secara tertulis ini dapat dilihat dari hasil pelaksanaan penelitian yaitu prosentase pada studi pendahuluan sebesar $29 \%$, atau hanya 5 siswa dari 17 siswa yang mampu menulis dengan baik yakni dapat mencapai nilai di atas nilai 67 atau nilai KKM pada aspek menulis. Hasil siklus I meningkat menjadi 47,05\% (kurang) karena dari 17 siswa 8 siswa yang berhasil memperoleh nilai di atas nilai $\mathrm{KKM}$, dan pada siklus II mengalami peningkatan sebesar $88,23 \%$ (sangat baik), dari 17 siswa yang dijadikan sampel ada 5 siswa dalam kategori sangat baik dan 10 siswa dalam kategori baik.

3. Proses pembelajaran mendeskripsi secara tertulis melalui penerapan pembelajaran kontekstual dengan memnfaatkan media gambar binatang yang cukup bervariasi dapat meningkatkan motivasi belajar, dan partisipasi aktif siswa. Hal ini dapat dilihat dari kerja sama antar siswa yang semakin meningkat, antusiasme siswa dalam belajar, kesungguhan siswa dalam mengerjakan tugas sekaligus mempresentasikan hasil kerjanya juga meningkat, siswa terlihat tertib dan gembira untuk selalu mengikuti pembelajaran dari awal sampai akhir pembelajaran.

4. Penggunaan pendekatan kontekstual oleh guru dalam pembelajaran juga meningkatkan keterampilan guru dalam pembelajaran. Dengan meng-gunakan pendekatan kontekstual guru jadi lebih responsif terhadap siswa, karena dengan adanya kelompok belajar mau tidak mau guru harus memberikan bimbingan terhadap setiap kelompok sehingga diskusi dalam kelompok lebih hidup dan tidak pasif. Selain itu, guru juga lebih aktif dan kreatif dalam memotivasi siswa dalam belajar, sehingga siswa lebih respon terhadap pembelajaran yang sedang berlangsung.

5. Kesalahan-kesalahan yang sering dilakukan siswa dalam mendeskripsi secara tertulis adalah meliputi kesalahan penggunaan atau pemilihan kata yang tepat dalam menggambarkan seekor binatang dengan baik sehingga cenderung berulang-ulang. Akan tetapi kesalahan-kesalahan tersebut dapat diatasi dengan pembelajaran berbasis kontekstual yang memanfaatkan media gambar binatang sebagai media alternatif dalam pembelajaran mendeskripsi secara tertulis siswa kelas II.

Setelah dilakukan penelitian di SDI Bhoanawa 2 Semester II Kecamatan Ende Selatan Kabupaten Ende dan berdasarkan hasil yang diperoleh di lapangan, maka diajukan saran kepada pihak yang berkaitan dengan masalah ini dalam hal ini pembaca, adalah sebagai berikut:

1. Bagi guru, dalam pembelajaran menulis khususnya menulis deskripsi diupayakan untuk menggunakan media baik berupa gambar ataupun model nyata sehingga mempermudah siswa untuk mendeskripsi objek dengan baik.

2. Bagi pihak-pihak lain yang ingin meneliti lebih lanjut, disarankan untuk mengembangkanpenerapan pembelajaran kontekstual dengan mendayagunakan 
media gambar dalam hal ini gambar binatang yang lebih kreatif dan bervariasi, sehingga lebih menarik minat siswa dalam kegiatan pembelajaran.

3. Bagi Kepala Sekolah, perlu mendiskusikan, mengimplementasikan dan menindaklanjuti strategi pembelajaran kontekstual dengan media gambar yang bervariasi pada setiap pembelajaran menulis khususnya dalam mendeksripsi secara tertulis pada siswa kelas III, IV, V, dan VI SD.

\section{DAFTAR PUSTAKA}

Zamzani, Z. (2014). Eksistensi Bahasa Indonesia dalam Pendidikan Berbasis Keragaman Budaya. Dialektika: Jurnal Bahasa, Sastra, dan Pendidikan Bahasa dan Sastra Indonesia, 1(2), 225-244.

Lakilaf, N. S., \& Suarjana, I. M. (2017). Penerapan Model Think-Pair-Share Untuk Meningkatkan Keterampilan Menulis Kelas Ii Sdn 3 Banjar Jawa. Jurnal Ilmiah Sekolah Dasar, 1(4), 284-287.

Nugraha, J., MS, Zulela., \& Fuad, N. (2019). Peningkatan keterampilan menulis deskripsi melalui pendekatan saintifik dengan metode problem based learning pada siswa kelas IV Sekolah Dasar. Prosiding Seminar Nasional Pendidikan KALUNI, Vol. 2, xx-xx. Jakarta: LPPM Universitas Indraprasta PGRI. Tersedia di: https://doi.org/10.30998/prokaluni.v2i $\underline{0.37}$ 